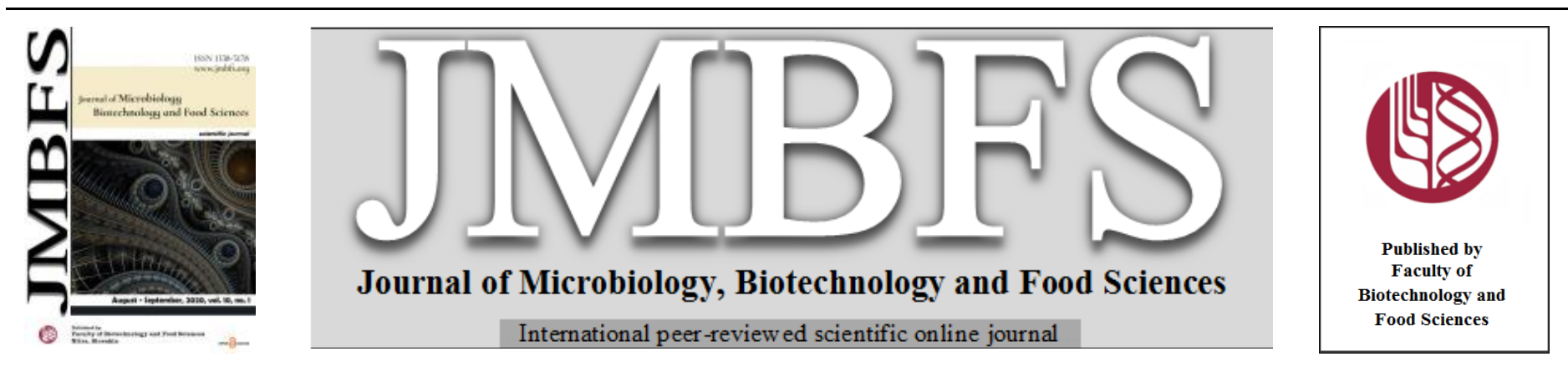

\title{
PHYCOREMEDIATION: A NOVEL AND SYNERGISTIC APPROACH IN WASTEWATER REMEDIATION
}

\author{
Sakshi Guleri ${ }^{l}$, Abhishek Saxena ${ }^{1}$, Kawal Jeet Singh ${ }^{1}$, Rinku $^{l}$, Raunak Dhanker $^{l}$, Neha Kapoor ${ }^{2}$, Archana Tiwari $^{1} *$
}

Address(es):

${ }^{1}$ Diatom Research Lab, Amity Institute of Biotechnology, Amity University, Noida, Uttar Pradesh, India.

${ }^{2}$ Department of Chemistry, Hindu College, University of Delhi, New Delhi, India.

*Corresponding author: panarchana@gmail.com

doi: 10.15414/jmbfs.2020.10.1.98-106

\section{ARTICLE INFO}

Received 14. 3. 2020

Revised 31. 3. 2020

Accepted 31. 3. 2020

Published 1. 8. 2020

\section{Review}

OPEN OACCESS $_{\text {A }}$

\begin{abstract}
Pollution such as water pollution got intensified with an increase in population density. So, it became important to deal with various industrial and household contaminants like dyes, heavy metals, microbes and radioactive materials. Hence, to remediate the water from such hazardous contaminants in a rapidly developing world, new technological inventions are required globally. Nanotechnology is getting increased attention as it is an advanced technology and shows advantages compared to other innovations. Various technologies are available in remediating water such as algal turf systems and nanoparticle-based adsorption. There are several ways of nanoparticle synthesis, but the algae-based synthesis is very significant and environment friendly. The potential and efficiency of algae in waste water remediation is remarkable and several contaminants can be detoxified, transformed and volatized by algae. There are several potential benefits associated with the algae mediated phycoremediation due to its advantages over conventional systems of remediation and heavy metal removal. Algal strains are easy to culture and adaptive in nature and can be easily manipulated within the laboratory. In this review, we have discussed the biological green nanoparticle synthesis using algae as an eco-friendly, cheap and cost-effective sustainable technology. However, algal mediated waste water treatment is yet in a primary stage and many innovative steps are necessary for adaptive remediation strategies, which can sustainably address global waste water issues.
\end{abstract}

Keywords: Algal Flow way systems, Microalgae, Nanoparticles, Phycoremediation, Water-remediation

\section{INTRODUCTION}

Water plays a major role for the functioning of ecosystems and the health of people. It is a universal solvent and with industrial and urban development it gets contaminated by many pollutants. So, its treatment becomes a necessity and several treatments have been implemented. In the last decades, developments in nanotechnology provides the opportunity of effective removal of pathogens and pollutants from water (Joshua et al., 2015). Wastewater affects us humans in different ways and a mix of industrial, agricultural, domestic waste and rainwater run-off makes wastewater contaminated with myriad of pollutants (Summer $\boldsymbol{e t}$ al., 2006). The characteristics of waste water vary depending on the source so that the composition of waste water differs from place to place. Wastewater is composed of microbes and wide range of contaminants such as dyes, (Karin, 2006), chemicals, synthetic organic or inorganic compounds, heavy metals, complex chemicals, radioactive substances, oil as shown in Table 1 .

Table 1 Different type of pollutants

\begin{tabular}{|c|c|c|c|}
\hline POLLUTANTS & TYPES & EXAMPLES & SOURCES \\
\hline \multirow{3}{*}{ PHYSICAL } & Sediments & Slit and soil & Soil erosion \\
\hline & Thermal pollution & Heat & Industries and power plants \\
\hline & Solid waste & & \\
\hline \multirow{4}{*}{ CHEMICAL } & Nutrients & Fertilizers & Agricultural and domestic waste \\
\hline & Toxic inorganic material & Acids, metals, Caustics, salts & Industrial and domestic effluents \\
\hline & $\begin{array}{l}\text { Persistent organic Pollutant } \\
\text { (POPs) }\end{array}$ & $\begin{array}{l}\text { Pesticides, plastics, detergents and } \\
\text { oils }\end{array}$ & $\begin{array}{l}\text { Industrial, domestic, agricultural } \\
\text { waste }\end{array}$ \\
\hline & Radioactive materials & Uranium, radon, thorium etc. & $\begin{array}{l}\text { Mining, power plants, natural } \\
\text { sources }\end{array}$ \\
\hline BIOLOGICAL & Pathogens, microbes & Bacteria, viruses, parasites & Sewage and human or animal excreta \\
\hline
\end{tabular}

The adulteration of various contaminants arising from diverse sources into the water makes it highly unsuitable for consumption. There are various side effects are also associated with the water pollution, which not only affect humans but also ecosystem functioning as shown in Figure 1. 

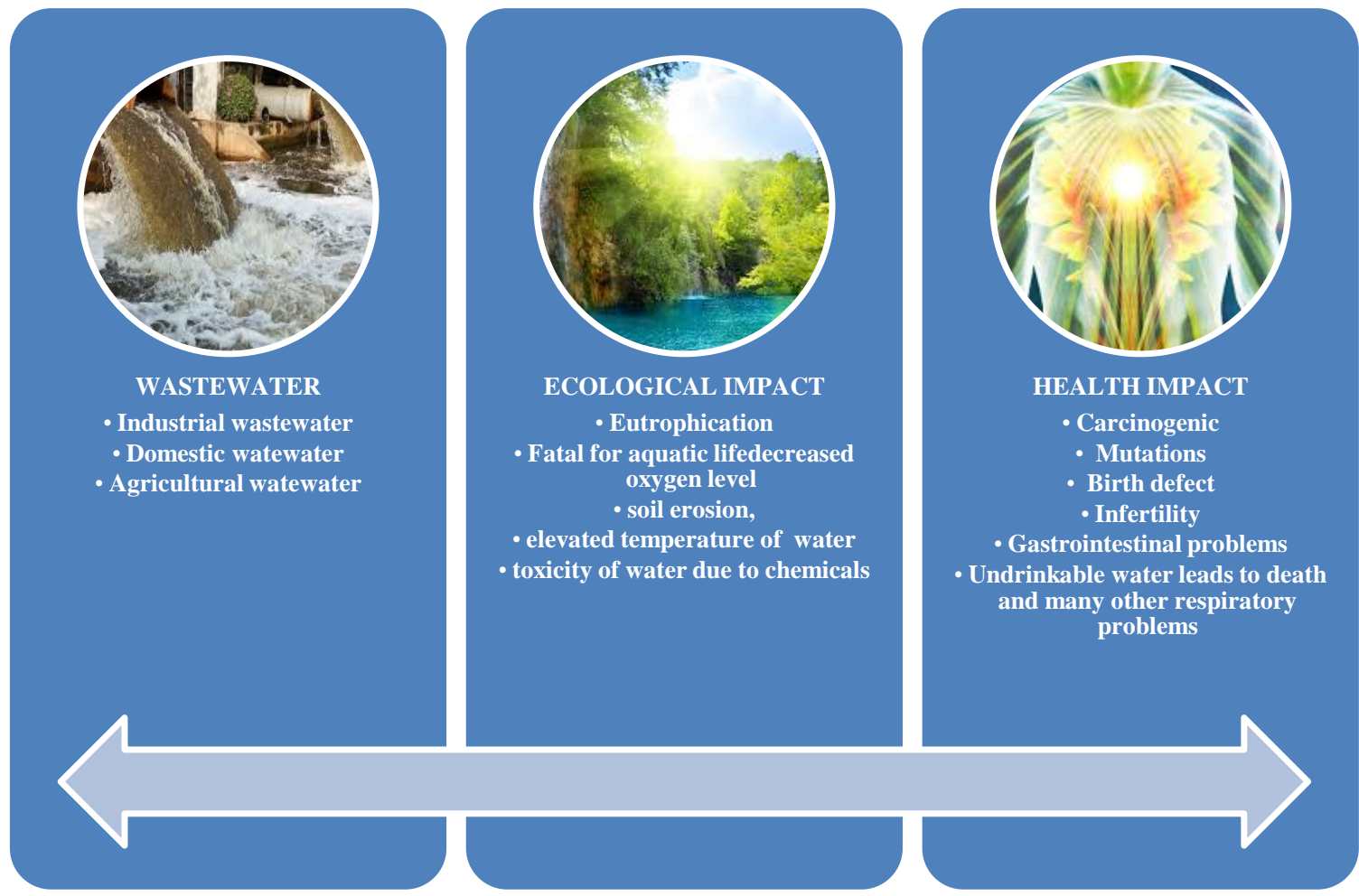

Figure 1 Impact of wastewater

There are several conventional methods to remediate the wastewater efficiently (American Public Health Association, 2005). The method of treating the waste water must be harmless to both humans and the environment. Besides being ecofriendly it must be done with least effort and economical. A sustainable way is provided by a biological treatment that is provided by bioremediation. Bioremediation is the most common technique used to treat waste water due to its low cost and environmentally friendly nature. Bioremediation is opted by almost every waste water treating industry (Gomez et $\boldsymbol{a l} ., \mathbf{2 0 0 8})$. The chemical and physical removal of contaminants is expensive and moreover less effective than bioremediation. A comparison is elaborated in Figure 2. Bioremediation is one of the practical approaches of biotechnology which involves the use of organisms for removing contaminants or pollutants from soil or water. The organisms that are involved can be bacteria or other microbes (Validi, 2001). The microbes break down the pollutants or decompose contaminants. If the contaminants are microbial pathogens, microbes involved in bioremediation inhibit the growth of pathogens or kill them (Murugesan and Rama Chandra, 2009).

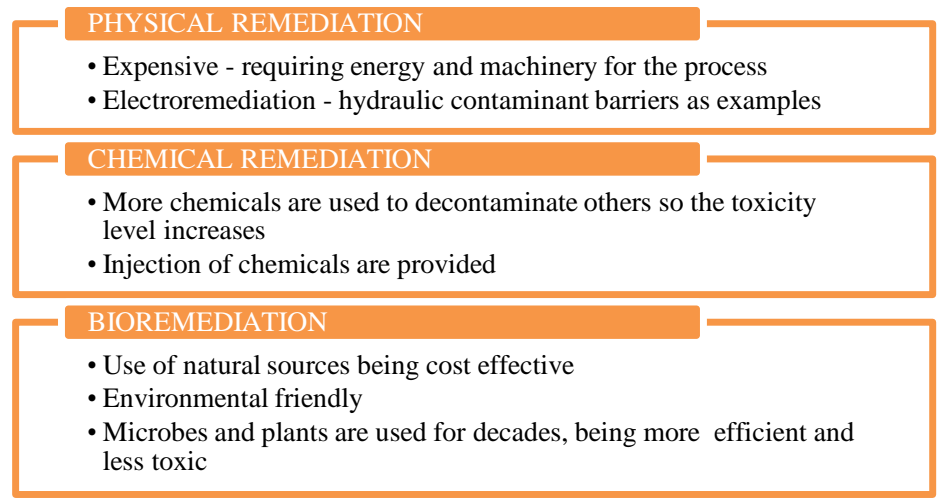

Figure 2 Comparison of bioremediation with other methods

Advantages and disadvantages of bioremediation strategies are shown below in Table 2. Bioremediation processes need optimal temperature, light, and other conditions to remediate waste water, if the right conditions are not available then it can be improved by adding amendments to the wastewater medium such as molasses, air or vegetable oil so that by utilizing them microbes establish optimal conditions to enhance the bioremediation process (Witters et al., 2012).
Table 2 Advantages and disadvantages of bioremediation technologies TECHNOLOGIES IN SITU BIOREMEDIATION (Bioventing, Biosparging)

Bioaugmentation, ADVANTAGES

- The contaminants can be fully transformed into totally harmless substances

- $\quad$ Cost effective

- $\quad$ Moisture, heat, temperature can be controlled

\section{EX SITU REMEDIATION}

(Biopiling, Composting, Farming)

\section{DISADVANTAGES}

- If in the whole process of biotransformation, intermediates is formed, it may sometimes be more toxic than the parent - Some compounds are nonbiodegradable

- Generates less amount of

waste

\section{Phycoremediation}

Phycoremediation involves micro- or macro-algae to remediate environment leading to the reduction or biotransformation of toxic compounds from waste water (Rao et al., 2011). Also, the use of microalgae is getting more attention not only due to its ability of effective removal of nutrients but to generate biomass allowing for biofuel production in addition (Pohl et al., 1988, Christenson et al.,
2011). The generation of biofuel is the additional advantage of cultivating algae (Ruiz-Martinez et al., 2012). It is a more conventional and sustainable method than any other method. Carbon dioxide sequestration is also done by microalgae and hence will help in controlling the rate of global warming, so the mass cultivation is required to attain the desired results (Becker, 1994). Algae occur worldwide in aquatic systems and have adapted to diverse conditions. This has additionally enabled the algae to develop a wide resistance to natural conditions 
including nutrient levels (Ahmad et al., 2017). This advantage prompted the wide utilization of the algae in bioremediation. Algae remove toxins like hydrocarbons, heavy metals and pesticides assisted by different processes like bioconcentration, biosorption, volatisation as well as biotransformation (Çicek at al., 2018). With the approach of genetic engineering, dynamic research became possible that improved the bioremediation possibilities with algal strains by improving their photosynthetic effectiveness, versatility and resilience to stressful conditions. Microalgae have a significant place in the tertiary treatment of residential wastewater, in the maturation of contaminated natural water bodies, or the treatment of small-middle-scale municipal wastewater in aerobic or facultative water bodies (Saravanan et al., 2015). They improve the expulsion of nutrients, pathogens, and heavy metals and provide oxygen to heterotrophic aerobic bacteria to mineralize organic pollutants, utilize carbon dioxide provided from heterotrophic organisms such as from the respiration of bacteria, fungi, and animals. Photosynthetic air circulation is in this way particularly intriguing to diminish task expenses and confines the dangers for poison volatilization under mechanical air circulation (Choi, 2016). Phycoremediation is an innovative technology that is gaining momentum in the field of environmental studies. Moreover, the majority of conventional strategies depend on physical displacement or chemical replacement, creating a secondary issue of toxic sludge as its disposal increases the load on the techno-economic feasibility of the treatment process. Hence, development of a new technique is essential to fulfill the environmental standards at much lower expenses. The main advantages of using microalgal species, is that it traps the solar energy through photosynthesis and absorbs $\mathrm{CO} 2$ along with nutrients from water to synthesize their biomass and produces oxygen. Algae release large amounts of organic compounds which can be assimilated by bacteria ( $\mathbf{L i}$ et al., 2017). The bacteria, in turn provide an important source of $\mathrm{CO}_{2}$ required for algal growth, and it changes the $\mathrm{pH}$ of the supporting medium (Jean-Luc Moue, 1995). Filamentous cyanobacteria are an excellent nominee for wastewater treatment due to their variable unique characteristics (Kudre et al., 2017). Algae are utilized by several industries, for instance the dairy industry. Primary and secondary treatment methods are quite common in the treatment of dairy wastewater as they are efficient and dependable. The dairy effluent is mainly organic in nature and due to its biodegradable constituents, it is amenable to conventional treatment. It is rich in nutrients, nitrate and phosphate, which is a source of improved algal growth in natural waterways. Fresh dairy sludge is very alkaline and becomes acidic due to fermentation of lactose to lactic acid. Because of these qualities chemical treatment techniques might not be suitable (Henaa et al., 2015). It is probably due to this reason that most of the existing dairies have treatment plants based on activated sludge processes. This type of treatment method is not effective in filtering the nutrients from dairy wastewater. This wastewater needs further polishing to remove the nutrients which can be effectively done through the use of aquatic macrophytes. Additionally, dairy waste contains adequate supplements for biological growth, biological treatment strategies are viewed as progressively perfect and efficient (Khemka et al., 2017). The treatment of dairy effluent by
Nostoc sp, is very efficient and it also proved to be a cost-effective and ecofriendly treatment. The Nostoc $s p$, has a significant job in the removal of COD, BOD, TSS, TDS and other metals (Gupta et al., 2015). Employing this innovation in the treatment of effluents exhibits an alternative instrument to the flow routine with regards to utilizing customary strategies, including physical and chemical technologies. The timely and cost-effective remediation of metal and natural contaminated sites mandate a comprehension of the degree and instruments by which dangerous metals hinder natural biodegradation. The components by which metals restrain biodegradation change with the organization and multifaceted nature of the framework under scrutiny and, furthermore, incorporate both physiological and environmental viewpoints. A careful comprehension of these frameworks, considering different dimensions of multifaceted nature is expected to develop new ways in dealing with the remediation of contaminated sites (Dadrasnia et al., 2015).

\section{Applications of algae}

\section{Industrial waste removal}

The probably largest industrial sector is the textile industrial sector and the textile industry utilizes large amounts of water and chemicals for their work process of textiles, and the consumption of water by textile industries vary from place to place and results in the release of effluents. Many steps are taken to utilize a minimum amount of water and recycle the waste water for further use (Ajayan and Selvaraju, 2012). The two important steps of the textile industries are dyeing and finishing. In these processes, considerable amounts of waste water and effluents are generated which are highly toxic and contain permanent colors which lead to fluctuating pH, BOD, and COD (Rajvaiday et al., 1998). Textile waste water, therefore, need great attention and effective removal of dye Remediation of water discharged from textile industries is made possible by algae. They are found to be effective in the reduction of chemical oxygen demand, reducing the $\mathrm{pH}$ (Ding et al., 2014). The industries use the algae of different species to remove various contaminants as indicated in Table 3. Also, the decolorization of azodyes were investigated using the algae Spirogyra spp. The maximum removal of dyes are possible using algae and the dye removal by algae is achieved by biosorption, diffusion, and bioconversion. Many species of algae have been successfully used in the treatment of waste water (Sengar $\boldsymbol{e t}$ al., 2011). Such waste waters consist of several pollutants, dissolved nitrogen and phosphorous which can be transformed by algae in the presence of carbon dioxide and light. The water can be remediated or renovated by the help of algae, which we refer as phycoremediation (Borowitzka, 1998). It is found that dairy cattle waste inhibits algal growth but now the researchers succeeded in growing algae on cattle manure. Also, it enhances the production of protein feed for algae and hence, efficiently remediates dairy waste water.

$\begin{array}{cl}\text { Table } 3 \text { Various species of algae and their } \\ \text { Sr. no. } & \text { Algal species } \\ 1 . & \text { Chlorella vulgaris } \\ 2 . & \text { Scenedesmus dimorphus } \\ 3 . & \text { S. incrassatulus } \\ 5 . & \text { Dunaliella } \\ 6 . & \text { Pithophora } \text { sp. }\end{array}$

\section{Microbial removal}

The discovery of therapeutic molecules is becoming important as many bacteria become resistant to most antibiotics. Antibacterial effects have been discovered in many species of algae specially the diatoms have a great potential (Kaaria $\boldsymbol{e}$ al., 2015). The antibacterial studies are not only important for studying the interactions on an ecological basis but also to study the capability of algae against other microbes and then finding their possible therapeutic applications (Kausalya et al., 2015). Several algal groups contain bioactive compounds with the potency of acting like antimicrobial agents. The metabolites of these organisms either primary or Secondary are being used by pharmaceutical industries to overcome many diseases (Venkatesan et al., 2007). In the past few decades, marine organisms are getting attention, especially macro- and microalgae, sponges, corals. Their bioactive compounds provide alternatives to many antibiotics and are helpful to combat deadly infections and fatal diseases (Kaaria et al., 2015). Microalgae or algae produce a wide range of compounds with biological activities. For example, they consist of antibiotics, toxins and pharmaceutically important compounds which have further use as therapeutics (Ruiz-Martinez $\boldsymbol{e}$ al., 2012). They have the antibacterial properties which helps in suppressing the growth or killing pathogenic bacteria or other pathogens.

\author{
References \\ Luz Estela Gonzalez, 1997 \\ Luz Estela Gonzalez, 1997 \\ Peña Castro et al., 2004 \\ Imani et al., 2011 \\ Brahmbhatt et al., 2012
}

\section{Nitrogen and Phosphorous Removal}

A novel method to reduce the effect of eutrophication is to remove nitrogen and phosphorous from waste water by means of algae (Bernhardt et al., 2008). The latest technology is a twin layer method where microalgae are immobilized by adhesion on substrate that needs to be wet and microporous and acts as a growth medium where the diffusion takes place (Apiratikul et al., 2004). With the help of this, the microalgae are able to remove phosphate, nitrate and ammonia within nine days which is very helpful in remediating wastewater

\section{Heavy Metal Removal}

The very first accumulators of metals in rivers or any other natural water sources are periphytons as they have a fast-regenerative process and higher biomass than others (Anjana et al., 2007). Microalgae or diatoms are key organisms in the periphyton and being considered as bioindicators, if there is any disturbance in the hydrosystem (Apiratikul et al., 2004). Diatoms have a silica cell wall called frustule and they have diverse forms depending upon the species. The growth cycle of diatoms can be fast with durations from hours to days. However, some interruptions or disturbance in the hydrosystem affects their development and growth. These non-natural factors include heavy metals which results in the deformations of the frustules (Nanda et al., 2010). Diatoms detoxify heavy metals by removing organic or inorganic compounds which are responsible for the formation of natural biofilms (Imani Saber et al., 2011). Diatoms are used as 
bioindicators of radioactive effluents as they accumulate radioactive minerals in their cell wall and this way remove them from water (Guasch et al., 2009).

\section{Algal Flow Way Systems}

One of the application of algae is that they are highly efficient in converting renewable solar energy and hence the production of many metabolites. And the world is taking advantage of this due to such properties of algae. Although many applications of algae have been explored still its economic constrains need to be addressed (Chen et $\boldsymbol{a l}$., 2015). There are commercial reactors for algal mass culturing, and all are developed as open flow way systems for instance, paddle wheels help in the circulation of culture. There are open shallow ponds where wheel is paddled to circulate the culture, but they have certain disadvantages This led to the use of photo bioreactors that are enclosed in which light sources are either artificial or natural (Williams et al., 2019). A method of removing nutrients, organic pollutants, or contaminants has been developed and that is known as algal turf which is used as a scrubber as well as it is also beneficial for biomass production of algae (Tilak et al., 2017). The principle of this technology is based on the fact that the scrubber also acts as growing surface for spores and algae provided on the water which is subjected to periodic water surge action and hence promotes ambient cellular water exchange. The light is supplied either by artificial mode or naturally and the turf is finally harvested before overgrown by algae (Walter et al., 2008). Algal turfs are networks consisting of accumulations of unicellular to branched filamentous algae. These are fastened to rock, plant stems and wood (Schulze $\boldsymbol{e t}$ al., 2017). Most algae have species which are present in turfs: green algae in fresh waters, brown and red algae in marine waters and diatoms and blue greens generally (D'Aiuto et al., 2015). Besides, they bolster epiphytes and enmeshed algal unicellulars are frequently kept up by fish and invertebrate slow eaters even with rivalry by bigger algae (Adeniyi $\boldsymbol{e}$ al., 2018). Algae give algal turfs an essential framework according to definition, they are biodiverse networks consisting of protozoans as well as little spineless creatures. Given solid current, flood or wave activity, daylight and ordinary brushing, algal turfs can effectively catch sunlight (D' Ippolito et al., 2015) Most single cells are photosynthetic, the productivity of algal turfs is additionally the consequence of elevated amounts of blending streaming water, constrained against cells by flood, significantly build synthetic trade. Moreover, photosynthesis in most higher plants and planktonic algal cells is biochemically upset in full sunlight, especially at high temperatures (Hampel et al., 2013). Mos significant, in any case, due to the forward and backward swashing of filaments in waves, singular cells get glimmering light and none of the cells are completely shaded by others (Ganesh et al., 2018). This permits an abnormal state of light harvest, and as estimated by $\mathrm{O}_{2}$ discharge, no hindrance is present even in ful tropical summer sun at late morning. A high extent of light vitality caught is exchanged to substance stockpiling as included biomass (Li et al., 2017). Alga turfs are without doubt, all around feebly repressed by low supplement levels (Liu et al., 2015). Singular cells can take-up carbon, phosphorus and nitrogen at portions of ppb levels. As the film of water neighboring every cell can't be depleted of supplements in a flood and stream condition, moderately abnorma amounts of profitability happen even at low supplement fixations (Lin et al.

Table 4 Applications of nanomaterials in pollutant removal TYPE OF NANOPARTICLES

Carbon Nanotubes

Metal Oxides Nanoscale

Nano Catalyst

Bioactive Nanoparticles (Ag, $\mathrm{Au})$

Biomimetic Membranes

Nanostructured Catalytic

\section{Synthesis of nanoparticles}

Various modes of the synthesis of nanoparticles has been implemented as per the requirement like physical, chemical and biological. Figure 3 shows the different methods for nanoparticle synthesis with examples, it can be easily understood by having a look at the figure.
2018). Notwithstanding utilizing raceway lakes for algal development, algal turf scrubbers have been utilized to give tertiary treatment of civil and horticultural wastewaters (Gismondi et al., 2016; Gügi et al., 2015; Kangas et al., 2017). An ATS is a since quite a while ago, slanted stream way that supports an alga biofilm and microorganisms. Wastewater washes over the stream path in a progression of blasts and furnishes the biofilm with supplements (Pandey $\boldsymbol{e t}$ al. 2015). The algae expel inorganic supplements, including phosphorus and nitrogen, from the wastewater, consequently lessening downstream eutrophication impacts. The supplements are expelled from the framework when the algal biomass (5\% to 6\% solids) is gathered by scratching (Pinto et al. 2018). These have exceptionally high supplement profluent content (around 2,000 milligrams for each litre of complete Kjehldahl nitrogen [mg/L TKN] 1 and around $500 \mathrm{mg} / \mathrm{L}$ of phosphorus) (Pandey $\boldsymbol{e t}$ al., 2016). These frameworks are not planned for amazing treatment, yet rather limit spillover into surface waters. Past research on ATS frameworks has concentrated on their adequacy in treating wastewater and the financial matters of the procedure yet has not connected life cycle techniques to measure natural effects. ATS frameworks can adequately treat wastewater in lab-scale contemplates (Úbeda et al., 2017) HydroMentia Inc. has likewise introduced ATS frameworks to treat rura spillover at business scales. Algal biomass created by ATSs has a low unsaturated fat content and is in this way inadequately appropriate for biodiesel generation (Pate et al., 2013). Therefore, biomass of algae is anaerobically processed to deliver biogas that is combusted for power generation.

\section{Nanotechnology in waste water treatment}

Nanotechnology provides an opportunity of upgrading waste water treatment Moreover, it has many advantages like cost effectiveness, reusability and being highly efficient in removing and recovering pollutants due to its high surface area. Nanoparticles such as gold, silver, titanium, copper, zinc and iron etc. can be synthesized through various microorganisms like E. coli, Lactobacillus, Pseudomonas, fungi and algae. These nanoparticles have antibacterial properties, and dye removal or heavy metal removal can be done with the help of such particles, hence being effective in remediating waste water (Kim et al., 2007). The defense mechanism of microbes helps in the synthesis of nanoparticles, for instance, the bacterial cell resistance for silver ions is responsible for its nanoparticle synthesis. Nanoparticles are a part of microbial metabolism and can be utilized for many other applications. Nanoparticle research is an emerging scientific field, due to various potential applications in biomedical, optics, electronics and waste water treatment. Nanoparticles are augmented as the materials having new or unique or progressive traits in comparison to other larger particles. Nanoparticles have properties like the surface to volume ratio is higher, high thermal conductivity, steadiness, non-linear optics, specificity (Buzea $\boldsymbol{e t}$ al. 2007). The applications of nanoparticles due to these properties are show in Table 4. Nanoparticles having such characteristics are currently playing significant roles in medical diagnostics, drug delivery systems, gene therapy applications, and tissue engineering and remediation too (Balantrapu et al., 2009).

\section{TYPE OF POLLUTANTS REMOVED}

Organic pollutants, contaminants

Heavy metals

Pesticides, azodyes

Antimicrobial, antibacterial

Salt removal

Inactivation of microbes, decompose pollutants
PHYSICAL METHODS

- MELT MIXING AND HIGH ENERGY BALL MILLING

- VAPOUR DEPOSITTION AND ION ABLATION ETC.

- ION IMPLANTATION

CHEMICAL METHODS

- COLLOIDS AND COLLOIDS IN SOLUTION

- SOL GEL METHOD

- CHEMICAL VAPOR DEPOSITION

BIOLOGICAL METHODS

- PLANT EXTRACTS OR ENZYMES

- MICROBES LIKE BACTERIA, FUNGI, ALGAE, DIATOMS

- TEMPLATES LIKE DNA, MEMBRANES

Figure 3 Different methods of nanoparticle synthesis 


\section{Green synthesis or biological synthesis}

Green or biological or biogenesis is an environmentally friendly method for nanoparticle synthesis with increased usage and applications of nanoparticles, it is required to develop an easy and environmentally sustainable or green path for nanoparticle development. Many routes were followed to develop nanoparticles like plant extracts, bacteria like lactobacillus or E. coli, fungi like Torilopsis, algae like $C$. vulgaris have been used but among all, microalgae got great attention since they are capable of bioremediating harmful toxins and subsequently transforming them into other useful compounds. In recent times, nanoparticles which are synthesized biologically got high attention in the area of molecular biology and therapeutics due to their unique properties (Vijayakumar et al., 2012).

\section{Algae used for nanoparticle synthesis}

The main types of nanomaterials that can be synthesized from algae are either metal nanoparticles or metal oxide nanoparticles (Asmathunisha et al., 2013) Table 5 shows a few algal strains used for both types of nanomaterials which are later discussed in detail.

\begin{tabular}{|c|c|c|c|c|}
\hline \multirow[t]{2}{*}{ MATERIALS } & NANOPARTICLE & SIZE & ALGAL SPECIES & REFERENCES \\
\hline & Silver & $45-80$ & Codium capitatum & Kannan et al., 2013. \\
\hline \multirow[t]{6}{*}{ Metals } & & $25-40$ & Padina gymnospora & Shiny et al., 2013. \\
\hline & & $45-76$ & Sargassum cinereum & Mohandass et al., 2013. \\
\hline & & $45-57$ & Gracilaria corticate & Naveena et al., 2013. \\
\hline & & 60 & Turbinaria conoides & Rajeshkumar et al., 201 \\
\hline & Gold & $10-30$ & Sargassum wightii & Singaraveluet al., 2007. \\
\hline & & $18-95$ & Stoechospermum marginatum & Arockiyaet al., 2012. \\
\hline \multirow[t]{5}{*}{ Metal oxide } & Copper oxide & $44-76$ & Bifurcaria bifurcate & Abboud et al., 2014. \\
\hline & Zinc oxide & $11-67$ & Sargassum muticum & Azizi et al., 2014 \\
\hline & & $55-80$ & Chlamydomonas reinhardtii & Rao et al, 2016 \\
\hline & & $30-57$ & Sargassum muticum & Azizi et al., 2014 \\
\hline & Iron oxide & $22-80$ & Sargassum muticum & Mahdavi et al., 2013 \\
\hline
\end{tabular}

A general procedure for the synthesis of algal based nanoparticles is demonstrated in figure 4 , showing a very simple and easy procedure to synthesize nanoparticles if the optimum conditions like temperature, $\mathrm{pH}$ and concentration of algal extract and metal salts are provided. The synthesis with biological mode generally takes the time of few hours to several days depending upon the strains.

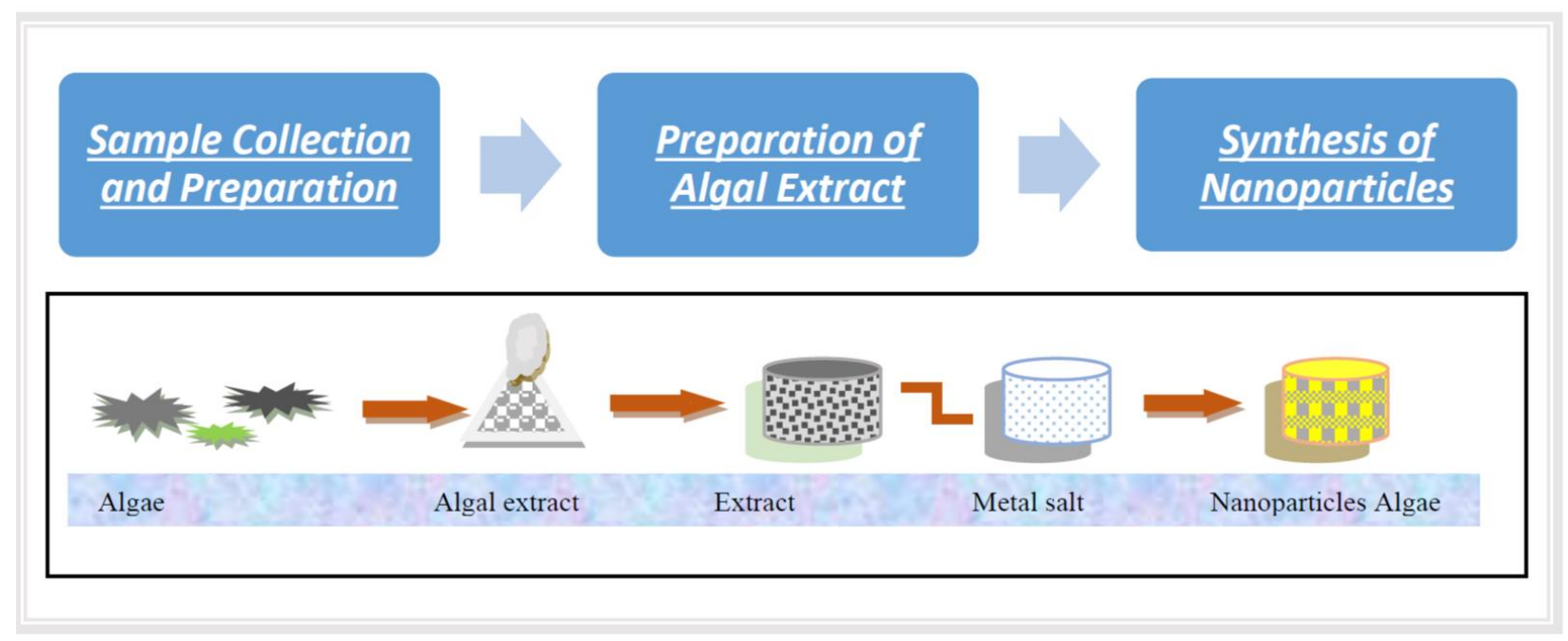

Figure 4 Nanoparticle synthesis from algal extract

\section{Synthesis of metal nanoparticles from algae}

The biological based synthesis of metal nanoparticles using different algal species from their salts is a simple process at room temperature. The synthesis can be easily initiated by mixing the solution of metal salt with aqueous algal extract. The color change of the reaction mixture indicates the synthesis of nanoparticles (Gericke et al., 2006). The studies have shown the various experimental factors responsible for the nano-synthesis of metals like algal extract concentration, concentration of metal salt, reaction time, temperature, and $\mathrm{pH}$.

Silver nanoparticles- Silver nanoparticles have properties like optical, thermal, electrical, conductance which are used in the development of products like chemical sensors to photovoltaics and from biosensors to diagnostic devices. Furthermore, they have antibacterial properties due to which they are used frequently in treating contaminants. For instance- pastes, conductive inks etc. use silver nanoparticles due to its unique property of high stability, high electrical conductivity and low sintering temperature. There are several applications of silver nanoparticles and many products are incorporated with such silver nanoparticles (Gilaki, 2010). A newly emerging application of AgNPs are antimicrobial bandages, wound coatings and devices, molecular diagnostics. The medical devices and wound dressings containing AgNPs slowly but steadily release levels of silver ions that provide protection against bacteria by killing them (Salari et al., 2016). Also, it is efficient in the removal of textile effluents, congo red dye, nitro-phenol etc.

\section{Gold nanoparticles}

Au nanoparticles have very unique size dependent properties and that have a wide variety of applications like as catalytic agents, biosensors, pharmaceuticals for imaging, and electronics and due to these properties researchers are focusing on the different methods to synthesize gold nanoparticles. Algae have been found as potential organisms for its synthesis (Arockiya et al., 2012). Researchers found that the functional groups present in microalgae have the capability of synthesizing stable particles with different shapes and these gold nanoparticles are helpful in removing dyes like methylene blue, methyl orange, and dichloromethane with potential applications in remediating wastewater (Parial $\boldsymbol{e t}$ al., 2012)

\section{Other metallic nanoparticles}

There are very less studies which show the synthesis of other metal nanoparticles like cadmium or palladium from algae. However, by the use of marine algae many types of nanoparticles have been synthesized like cadmium sulphide (CdS) 
nanoparticles. And spherical palladium (Pd) nanoparticles (Rajvaiday and Markendey, 1998).

\section{Synthesis of metal oxide nanoparticles by algae}

Metalloxides come under the class of organic material and due to their wide range of properties and structures they are being explored extensively. Their characteristics are more complex than those of other pure metal nanomaterials. They have unique properties as they possess different compositions and physiochemical structures which are further utilized in catalytic, magnetic, solar energy, and remediation applications. Current studies show very less or limit the synthesis of metal oxide nanoparticles by the algae.

\section{Zinc oxide nanoparticles}

Zinc oxide nanoparticles have certain applications in the removal of heavy metals from water like arsenic removal, cadmium removal, formaldehyde, phenol, and various dyes like brown CGG, organic dyes, methylene blue and malachite green dye. One of the algae which is used for its synthesis is Cystophora spp. (Shamsuzzaman et al., 2013).

\section{Iron oxide nanoparticles}

Iron oxide nanoparticles have many applications especially in terms of water remediation as they are helpful not only in remediating heavy metals like chromium, lead, nickel, but also radioactive materials like uranium, dissolved sulphates and nitrates.

\section{Nanoparticles supported adsorbent models for waste water remediation (Nanoadsorbents)}

Adsorption is an effective, economical, and ecofriendly technique that has potential to make water reusable and also fulfill high quality standards of effluents in the industries (Pan and Xing, 2008). This technique involves the process of transferring the substance from the liquid phase to the solid surface and this is subjected to physical and chemical interactions. Adsorption can be done batch wise, semi batch or continuous. The adsorption can be of two types either physical or chemical depending upon their intermolecular attractive forces The Physical adsorption occurs when the adsorbate gets attached to adsorben through van der Waal forces whereas chemical adsorption occurs through surface modifications and with the help of electronic bonds. There are several adsorbents available, but it is necessary to use low cost adsorbents for effective removal of contaminants. Zeolites, peat moss, activated carbon, and neem bark are very efficient adsorbents. Agricultural wastes or their byproducts can also be utilized as low-cost adsorbents. Adsorbents must have thermal and chemical selectivity, kinetic characteristics and stability. Adsorbents must have regeneration capacity and low solubility in liquids. Various low-cost adsorbents are derived from wastes and nowadays diatomaceous earth is also utilized as adsorbent. The reason for using these adsorbents is that they are economical. In last few decades the new type of adsorbents has been developed to conquer the problem of waste water so that one can reuse it and that are nanoadorbents. Various types of nanomaterials have been synthesized like carbon nanotubes, nanocages, nanorods etc. (Narr et al., 2007). Metal oxide nanoparticles exhibits higher adsorption properties as compared to normal sized oxides. Wastewater is commonlyloaded with very hazardous pollutants and contaminants so treatment with those nanoadorbents is necessary as they are highly efficient compared to other adsorbents. Nanomaterials as adsorption material emerged as one of the technologies with great potential to solve the problem of waste water treatment. Some distinctive properties of nanoadsorbents like their small size and high surface area make them unique. This technology is the revolution for waste water treatment technologies capable to revolutionize the wastewater treatment. For instance, silver nanoparticles have been implemented in the fabrication of adsorption models (Dominika $\boldsymbol{e t}$ al., 2019). This technology is the revolution for waste water treatment technologies capable to revolutionize wastewater treatment. Figure 5 demonstrates the process of waste water remediation by adsorption processes. There are a number of water purification procedures, yet adsorption is a standout amongst the easiest, compelling, and affordable techniques for wastewater purification (Marichelvam et al., 2018). In this article a plethora of solid adsorbents are mentioned, like natural adsorbents, agricultural wastes, industrial wastes, biomass, nanoadsorbents: carbon-based nanomaterials, novel metal-based nanomaterials, metal oxide-based nanomaterials (Xinling et al., 2019), Spinel ferrite based nanomaterials, nanocomposites, dendritic polymers, geopolymer cement have been mentioned for the expulsion of various pollutants from waste water. Removal of fluoride, phosphate, nitrate and radionuclides from wastewater can be removed by such adsorption models (Venkata et al., 2018). Adsorption isotherm models, kinetic models, thermodynamic parameters and adsorption mechanism can be examined after whole adsorption process (Tanweer et al., 2018). The present article records distinctive types of adsorbents and surveys best in class of the removal of different pollutants from water (Juntao et al., 2018). Sources of contamination and toxicities of pollutants have also been discussed. Adsorption mechanisms responsible for pollutants removal by different adsorbents have been reviewed (Abhishek et al., 2017). The present review demonstrates late advancements of nanotechnology in the synthesis of nanoadsorbents (Menghua et al., 2017). The primary target of this review is to depict adaptable ways of phycosynthesized nanoparticles and their capacity to adsorb variety of inorganic contaminants which are available in the water (Andrea et $\boldsymbol{a l}$. , 2019). It is evident from the review that synthesized nanoparticles (low-cost adsorbents) have demonstrated high removal capabilities for certain inorganic contaminants from water.

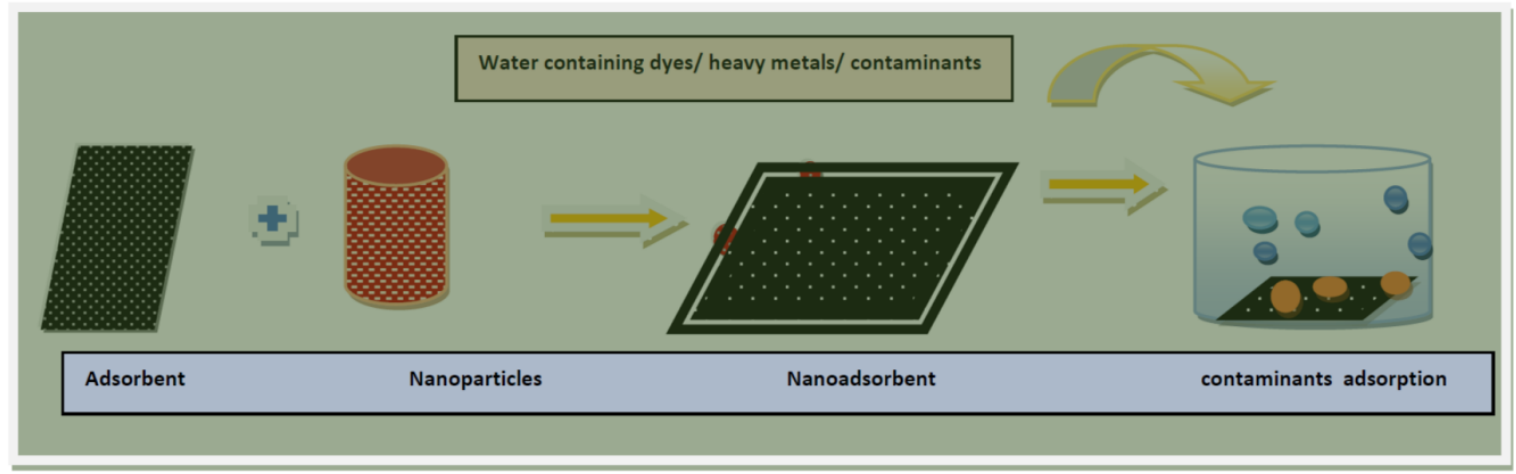

Figure 5 Effective contaminant removal by nanoadsorbents

Because of environmental dangers of effluents, treatment is fundamental before disposal. It may lead to improved water and/or oil segregation, oil recovery, improved quality of water, reuse of water, downstream facility protection and environmental permit compliance (Ana et al., 2016). Numerous methods are there for segregation of oil-water emulsions, counting different filters (Hendrik et al., 2016), chemical dosing, RO, separation by gravity, micro-filtration, ultrafiltration (Rui-Lin et al., 2015), biological processes (Amit et al., 2015), air flotation (Arshad et al., 2015), membrane bioreactor (Haicheng et al., 2015), chemical coagulation, electrocoagulation and electroflotation (Imran Ali et al., 2016). One common method for the removal of water dissolved organics is adsorption. It includes detachment of substances from the liquid phase to a surface.

\section{CONCLUSION}

The removal of nutrients from high organic content waste water is possible by phycoremediation as it has the great potential to mediate eutrophication in the several regions of world. However, more development is still required in this field. The points that can be concluded from this study are: a) Micro- or macroalgae show a high efficacy of nutrient removal. b) Algae are effective in sludge decomposition. Before commercialization or industrial acceptance more studies are required to scale up phycoremediation technology in order to remove waste by utilizing biomass as well. India as a tropical country with abundant solar irradiation is particularly suited for the application of phycoremediation. The invention of algal flow way systems is leading to the development and harvesting of algal turf. These turfs utilize natural as well as artificial light to promote the growth of algae and they are very efficient scrubbers of carbon dioxide, organic pollutants or nutrients found in waste water as well as in natural waters. The biogenic production of various types of nanoparticles is receiving high attention due to its ease and effectivity. Several bacteria and plants are able to synthesize nanoparticles. Now researchers are focusing on the development of nanoparticles through algae. Nanoparticles may have great antibacterial properties has and a great potential in treating waste water whether it comes from sewage, textile, agricultural or other sources. More investigations will be helpful in explore the potential of microalgae to synthesize many other metallic nanoparticles that have other applications in the pharmaceutical, food, cosmetic, medical and wastewater 
treatment industries. The microalgae can be used for the synthesis of nanoparticles and their biogenesis is getting favored compared to chemical and physical synthesis of nanoparticles. Their biosynthesis is safe, economic, cheap, cost effective, and ecofriendly. More research is needed for the development of nanoadsorbents in wastewater treatment. The investigation and studies about their adsorption abilities make them more productive and reusable at large scale. Furthermore, other adsorbent models or materials should be investigated such as the wood bark, activated carbon, sieves, membranes and their applications in the regeneration of wastewater.

Acknowledgement: The authors are thankful to the Department of Biotechnology, (DBT), New Delhi, India for providing financial support under project Grant No: BT/PR/15650/AAQ/3/815/2016. Prof. Dr. Hans-Uwe Dahms (KMU, Kaohsiung) is acknowledged for helpful advices and English corrections of an edited version.

Conflict of interest: There is no conflict of interest for authorship among the authors.

\section{REFERENCES}

Mandal, A., Singh, N., \& Nain, L. (2017). Agro-waste biosorbents: Effect of physico-chemical properties on atrazine and imidacloprid sorption. Journal of Environmental Science and Health, Part B, 52 (9), 671-682. https://doi.org/10.1080/03601234.2017.1331677

Adeniyi, O. M., Azimov, U., \& Burluka, A. (2018). Algae biofuel: current status and future applications. Renewable and Sustainable Energy Reviews, 90, 316335. https://doi.org/10.1016/j.rser.2018.03.067

Ahmad, A., Bhat, A. H., \& Buang, A. (2017). Biosorption of transition metals by freely suspended and Ca-alginate immobilized with Chlorella vulgaris: kinetic and equilibrium modeling. Journal of Cleaner Production, 171, 1361-1375. https://doi.org/10.1016/j.jclepro.2017.09.252

Ajayan, K. V., \& Selvaraju, M. (2012). Heavy metal induced antioxidant defense system of green microalgae and its effective role in phycoremediation of tannery effluent. Pakistan Journal of Biological Sciences, 15(22), 1056-1062. https://doi.org/10.3923/pjbs.2012.1056.1062

American Public Health Association. 2005. Standard methods for the examination of water and wastewater. Washington (DC): APHA.

Bhatnagar, A., Sillanpää, M., \& Witek-Krowiak A. (2015). Agricultural waste peels as versatile biomass for water purification $-\mathrm{A}$ review. Chemical Engineering Journal, 270, 244-271. https://doi.org/10.1016/j.cej.2015.01.135 Vida, A.C.F., Cocovi-Solber, D.J., Zagatto, E.A.G., Miró, M. (2016). Rapid estimation of readily leachable triazine residues in soils using automatic kinetic bioaccessibility assays followed by on-line sorptive clean-up as a front-end to liquid

78.https://doi.org/10.1016/j.talanta.2016.04.062

Fiorati, A., Pastori, N., Punta, C., \& Melone, L. (2019). Spongelike Functiona Materials from TEMPO-Oxidized Cellulose Nanofibers Nanosponges:Synthesis and Applications, 123-141. https://doi.org/10.1002/9783527341009.ch4

Anjana, K., Kaushik, A., Kiran, B., \& Nisha, R. (2007). Biosorption of Cr (VI) by immobilized biomass of two indigenous strains of cyanobacteria isolated from metal contaminated soil. Journal of Hazardous Materials, 148(1-2), 383-386. https://doi.org/10.1016/j.jhazmat.2007.02.051

Apiratikul, R., Marhaba, T. F., Wattanachira, S., \& Pavasant P. (2004) Biosorption of binary mixtures of heavy metals by green macroalga, Caulerpalentillifera. Songklanakarin. Journal of Science Education and Technology, 26(1), 199-207.

Arockiya, A.R.F., Parthiban, C., Ganeshkumar, V., \& Anantharaman, P. (2012). Biosynthesis of antibacterial gold nanoparticles using brown alga Stoechospermum marginatum(kützing). Spectrochimica Acta Part B: Molecular and Biomolecular Spectroscopy, 99, 166-173. https://doi.org/10.1016/i.saa.2012.08.081

Mehmood, A., Bano, S., Fahim, A., Parveen, R., \& Khurshid, S. (2015). Efficient removal of crystal violet and eosin B from aqueous solution using Syzygiumcumini leaves: A comparative study of acidic and basic dyes on a single adsorbent. Korean Journal of Chemical Engineering, 32, 882-895. https://doi.org/10.1007/s11814-014-0308-8

Asmathunisha, N., \& Kathiresan, K. (2013). A review on biosynthesis of nanoparticles by marine organisms. Colloids and Surfaces B: Biointerfaces, 103 , 283-287. https://doi.org/10.1016/j.colsurfb.2012.10.030

Azizi, S., Ahmad, M. B., Namvar, F., \& Mohamad, R. (2014). Green biosynthesis and characterization of zinc oxide nanoparticles using brown marine macroalgaSargassummuticum aqueous extract. Materials Letters 116, 275-277.

Balantrapu, K., \& Goia, D.V. (2009). Silver nanoparticles for printable electronics and biological applications. Journal of Materials Research, 24(9), 2828-2836. https://doi.org/10.1557/jmr.2009.0336

Becker, E. W. 1994. Microalgae: Biotechnology and Microbiology. Cambridge (MA): Cambridge University Press.

Bernhard, E.S., Lawrence, E. B., Walsh, C. J., \& Berke, P. E. (2008) Understanding, managing, and minimizing urban impacts on surface water nitrogen loading. National Academy of Sciences Year in Ecology and Conservation Biology, 1134(1), 61-96. https://doi.org/10.1196/annals.1439.014

Borowitzka, M. A. 1998. Limits to growth. In: Wong YS, Tam NFY, editors Wastewater Treatment with Algae. New York (NY): Springer-Verlag, 203-226. Brahmbhatt, Rinku, N.H., Patel, V., \& Jasrai, R.T. (2012). Removal of cadmium, chromium and lead from filamentous alga of Pithophora $s p$. of industrial wastewater. International Journal of Environmental Sciences, 3(1), 408-411. https://doi.org/10.1557/jmr.2009.0336

Buzea, C., Pacheco II., \& Robbie, K. (2007). Nanomaterials and nanoparticles: sources and toxicity. Biointerphases 2(4),

$17-71$ https://doi.org/10.1116/1.2815690

Chen, N., Li, J., Wu, Y., Kangas, P.C., Huang, B., Yu, C., \& Chen, Z. (2015) Nutrient removal at a drinking water reservoir in China with an algal floway. Ecological Engineering, https://doi.org/10.1016/j.ecoleng.2015.09.049

Choi, H.J. (2016). Dairy wastewater treatment using microalgae for potential biodiesel application. Environmental Engineering Research, 21(4), 393-400. https://doi.org/10.4491/eer.2015.151

Christenson, L., \& Sims, R. (2011). Production and harvesting of microalgae for wastewater treatment, biofuels, and bioproducts. Biotechnology Advances, 29(6), 686-702. https://doi.org/10.1016/j.biotechadv.2011.05.015

Cicek, A., Yilmaz, O., \& Arar, O. (2018). Removal of lithium from water by aminomethyl phosphonic acid-containing resin. Journal of Serbian Chemical Society, 83(9), 1059-1069. https://doi.org/10.2298/JSC170930020C

D’Aiuto, P.E., Patt, J.M., Albano, J.P., Shatters, R.G., \& Evens, T. (2015). Algal turf scrubbers: periphyton production and nutrient recovery on a South Florida citrus farm. Ecological Engineering, 75, 404-412. https://doi.org/10.1016/j.ecoleng.2014.11.054

D’Ippolito, G., Sardo, A., Paris, D., Vella, F.M., Adelfi, M.G., Botte, P., Gallo, C., \& Fontana, A. (2015). Potential of lipid metabolism in marine diatoms for $\begin{array}{lllll}\text { biofuel production. Biotechnology for Biofuels, } 8, & 28 .\end{array}$ https://doi.org/10.1186/s13068-015-0212-4

Dadrasnia, A., \& Ismail, S. (2015). Biosurfactant production by Bacillus salmalaya for lubricating oil solubilization and biodegradation. International Journal of Environmental Research, 12(8), 9848-9863. https://doi.org/10.3390/ijerph120809848

Ding, J., Zhao, F., Cao, Y., Xing, L., Liu, W., Mei, S., \& Li, S. (2014) Cultivation of microalgae in dairy farm wastewater without sterilization. International Journal of Phytoremediation, 17(1-6), 222-227. https://doi.org/10.1080/15226514.2013.876970

Pawcenis, D., Chlebda, D.K., Jędrzejczyk, R.J., Leśniak, M., Sitarz, M., \& Łojewska, J. (2019). Preparation of silver nanoparticles using different fractions of TEMPO-oxidized nanocellulose. European Polymer Journal, 116, 242-255. https://doi.org/10.1016/j.eurpolymj.2019.04.022

Saratale, R.G., Kumar, G., Banu, R., Xia, A., Periyasamy, S., \& Saratale, G.D. (2018). A critical review on anaerobic digestion of microalgae and macroalgae and co-digestion of biomass for enhanced methane generation. Bioresource Technology 262, 319-332. https://doi.org/10.1016/j.biortech.2018.03.030

Gericke, M., \& Pinches, A. (2006). Biological synthesis of metal nanoparticles. Hydrometallurgy, 83(1-4), 132-140. https://doi.org/10.1016/j.hydromet.2006.03.019

Gismondi, A., Pippo, F.D., Bruno, L., Antonaroli, S., \& Congestri, R. (2016) Phosphorus removal coupled to bioenergy production by three cyanobacterial isolates in a biofilm dynamic growth system. International Journal of Phytoremediation, 18(9).

876.https://doi.org/10.1080/15226514.2016.1156640

Go'mez, N., Sierra, M.V., Cortelezzi, A., \& Capı'tulo, A.R. (2008). Effects of discharges from the textile industry on the biotic integrity of benthic assemblages. Ecotoxicology and Environmental Safety, 69(3), 472-479. https://doi.org/10.1016/j.ecoenv.2007.03.007

Guasch, H., Leira, M., Montuelle, B., Geiszinger, A., Roulier, J. L., Tornés , E. $\&$ Serra, A. (2009). Use of multivariate analyses to investigate the contribution of metal pollution to diatom species composition: search for the most appropriate cases and explanatory variables. Hydrobiologia, 627, 143-158 https://doi.org/10.1007/s10750-009-9721-0

Gügi, B., Le Costaouec, T., Burel, C., Lerouge, P., Helbert, W., \& Bardor, M. (2015). Diatom-specific oligosaccharide and polysaccharide structures help to unravel biosynthetic capabilities in diatoms. Marine Drugs, 13(9), 5993-6018. https://doi.org/10.3390/md13095993

Gupta, V. K., Nayak, A., \& Agarwal, S. (2015). Bioadsorbents for remediation of heavy metals: Current status and their future prospects. Environmental Engineering Research, 20(1), 1-18. https://doi.org/10.4491/eer.2015.018

Liu, H., \& Chen, W. (2015). Magnetic mesoporous imprinted adsorbent based on $\mathrm{Fe}_{3} \mathrm{O}_{4}$ modified sepiolite for organic micropollutant removal from aqueous solution. Royal Society of Chemistry Advances,5(34), 27034-27042. https://doi.org/10.1039/C5RA00985E

Adey, W.H., Laughinghouse, H.D., 4th, Miller, J.B., Hayek, L.A., Thompson, J.G., Bertman, S., Hampel, K., \& Puvanendran, S. (2013). Algal turf scrubber (ATS) floways on the Great Wicomico River, Chesapeake Bay: productivity, 
algal community structure, substrate and chemistry. Journal of Phycology, 49(3), 489-501.https://doi.org/10.1111/ipy.12056

Hena, S., Fatimah, S., \& Tabassum, S. (2015). Cultivation of algae consortium in a dairy farm wastewater for biodiesel production. Water Resources and Industry, 10, 1-14. https://doi.org/10.1016/j.wri.2015.02.002

Laube, H., \& Reza, M.T. (2016). Application of biosorbents for ion removal from sodium lactate fermentation broth. Journal of Environmental Chemical Engineering, 4 (1), 10-19. https://doi.org/10.1016/j.jece.2015.10.044

Ali, I., ALOthman, Z. A., \& Al-Warthan, A.,(2015). Sorption, kinetics and thermodynamics studies of atrazine herbicide removal from water using iron nano-composite material. International Journal of Environmental Science and Technology,13, 733-742. https://doi.org/10.1007/s13762-015-0919-6

Imani Saber, I., Rezaei-Zarchi, S., Hashemi, M.,Borna, H., Javid, A., Zand, A.M. \& Abarghouei, H.B. (2011). Hg, $\mathrm{Cd}$ and $\mathrm{Pb}$ heavy metal bioremediation by Dunaliella alga. Journal of Medicinal Plants Research, 5(13), 2775-2780. ISSN 1996-0875 C2011 Academic Journals

Ali, I., AL-Othman, Z.A., \& Alwarthan, A. (2016). Green synthesis of functionalized iron nano particles and molecular liquid phase adsorption of ametryn from water. Journal of Molecular Liquids, 221, 1168-1174 https://doi.org/10.1016/i.molliq.2016.06.089

Halder, J.N., \& Islam, M.N. (2015). Water Pollution and its Impact on the Human Health. Journal of Environment And Human, 2(1), 2373-8332. https://doi.org/10.15764/EH.2015.01005

Tang, J., Song, Y., Zhao, F., Spinney, S., Bernardes, J.S., \& Tam, K.C. (2018) Compressible cellulose nanofibril (CNF) based aerogels produced via a bioinspired strategy for heavy metal ion and dye removal. Carbohydrate Polymers, 208, 404-412. https://doi.org/10.1016/j.carbpol.2018.12.079

Kaaria, P., Matiru, V., Wakibia, J.G., Bii, C., \& Ndung, M. (2015). Antimicrobia Activity of Marine Algae Associated Endophytes and Epiphytes from the Kenya Coast. International Journal of Current Microbiology and Applied Sciences, 3(3), 70-74.https://doi.org/10.12691/jaem-3-3-2

Kangas, P., Mulbry, W., Klavon, P., Laughinghouse, H.D., \& Adey, W, (2017). High diversity within the periphyton community of an algal turf scrubber on the Susquehanna River. Ecological Engineering, 108, 564-572. https://www.researchgate.net/deref/http $\% 3 \mathrm{~A} \% 2 \mathrm{~F} \% 2 \mathrm{Fdx} . d o i . o r g \% 2 \mathrm{~F} 10.1016 \% 2$ Fj.ecoleng.2017.05.010

Kannan, R. R. R., Stirk, W.A., \& Staden, J.V. (2013). Synthesis of silver nanoparticles using the seaweed Codiumcapitatum P.C. Silva (Chlorophyceae) South African Journal of Botany, 86, 1-4 https://doi.org/10.1016/j.sajb.2013.01.003

Larsdotter, K. (2006). Wastewater Treatment with Microalgae-A Literature Review. Vatten, 62, 31-38

Kausalya, M., \& Narasimha Rao, G.M. (2015). Antimicrobial activity of marine algae. Journal of Algal Biomass Utilization., 6(1), 78- 87. ISSN: $2229-6905$ Khemka, A., \& Saraf, M. (2017). Strategic enhancement of Desertifilumtharense MSAK01 on dairy wastewater: an integrated approach for remediation and biomass production. Applied Water Science, 7, 27792785. http://doi.org/10.1007/S13201-017-0525-5

Kim, J. S., Kuk, E., Yu, K. N., Kim, J., Park, S. J.,\& Lee, H. J. (2007) Antimicrobial effects of silver nanoparticles. Nanomedicine Nanotechnology Biomedicine, 3(1), 95-101. https://doi.org/10.1016/j.nano.2006.12.001

Kudre, T. G., Bhaskar, N., \& Sakhare, P. Z. (2017). Optimization and characterization of biodiesel production from rohu (Labeorohita) processing waste. Renewable Energy, 113,1408-1418 https://www.researchgate.net/deref/http $\% 3 \mathrm{~A} \% 2 \mathrm{~F} \% 2 \mathrm{Fdx}$.doi.org\%2F10.1016\% 2Fj.renene.2017.06.101

Li, P. S., \& Tao, H. C. (2015). Cell surface engineering of microorganisms towards adsorption of heavy metals. Critical Reviews in Microbiology, 41(2), 140-149. https://doi.org/10.3109/1040841X.2013.813898

Li, X., Marella, T.K., Tao, L., Li, R., Tiwari, A., \& Li, G. (2017). Optimization of growth conditions and fatty acid analysis for three freshwater diatom isolates. Phycological Research, 65, 177-187. https://doi.org/10.1111/pre.12174

Lin, Q., Zhuo, W. H., Wang, X. W., Chen, C.P., Gao, Y. H., \& Liang, J. R (2018). Effects of fundamental nutrient stresses on the lipid accumulation profiles in two diatom species Thalassiosira weissflogii and Chaetoceros muelleri. Bioprocess and Biosystems Engineering, 41(8), 1213-1224. https://doi.org/10.1007/s00449-018-1950-z

Liu, J., \& Vyverman, W. (2015). Differences in nutrient uptake capacity of the benthic filamentous algae Cladophora sp., Klebsormidium sp. and Pseudanabaena sp. under varying N/P conditions. Bioresource Technology, 179, 234-242. https://doi.org/10.1016/j.biortech.2014.12.028

Gonzalez, L.E., Canizares, R.O., \& Baena, S. (1997). Efficiency of ammonia and phosphorous removal from a Colombian agroindustrial wastewater by the microalgae Chlorella vulgaris and Scenedesmus dimorphus. Bioresource Technology, 60(3), 259-262. https://doi.org/10.1016/S0960-8524(97)00029-1

Mahdavi, M., Namvar, F., Ahmad, M. B., \& Mohamad, R. (2013). Green biosynthesis and characterization of magnetic iron oxide $\left(\mathrm{Fe}_{2} \mathrm{O}_{3}\right)$ nanoparticles using seaweed (Sargassummuticum) aqueous extract. Molecules, 18(5), 5954 5964. https://dx.doi.org/10.3390\%2Fmolecules18055954
Marichelvam, M. K., \&Azhagurajan, A. (2018). Removal of Mercury from Effluent Solution by using Banana Corm and Neem Leaves Activated Charcoal. Environmental Nanotechnology, Monitoring \& Management, 10, 360365.https://doi.org/10.1016/j.enmm.2018.08.005

Li, M., Jiao, C., Yang, X., Wang, C., Wu, Q., \&Wang, Z. (2017). Solid phase extraction of carbamate pesticides with banana peel derived hierarchical porous carbon prior to high performance liquid chromatography. Analytical Methods, 9 (4), 593-599. https://doi.org/10.1039/C6AY02678H

Mohandass, C., Vijayaraj, A. S., Rajasabapathy, R., Satheeshbabu, S., Rao, S. V., Shiva, C., \& De-Mello, I. (2013). Biosynthesis of Silver Nanoparticles from Marine Seaweed Sargassum cinereum and their Antibacterial Activity. Indian Journal of Pharmaceutical Sciences, 75(5), 606-610. https://www.ncbi.nlm.nih.gov/pmc/articles/PMC3877525/

Rajasulochana, P., Dhamotharan, R., Murugesan, S., \& Murthy, A.R. (2009). A bioremediation of oil refinery effluent by using Scenedesmus Obliquus. Journa of American Science, 5(4), 17-22. http://www.americanscience.org/

Nanda, S., Sarangi, P. K., \& Abraham, J. (2010). Cyanobacterial remediation of industrial effluents II. paper mill effluents. New York Science Journal, 3(12), 32 36. http://www.sciencepub.net/newyork

Narr, J., Viraraghavan, T., \& Jin, Y.C. (2007). Applications of nanotechnology in water/wastewater treatment: a review. Fresenius Environmental Bulletin, 16(4), 320-329. ISSN:1018-4619

Naveena, B. E., \& Prakash, S.(2013). Biological synthesis of gold nanoparticles using marine algae Gracilariacorticata and its application as a potent antimicrobial and antioxidant agent. Asian Journal of Pharmaceutical and Clinical Research, 6(2), 179-182.

Pan, B., \& Xing, B. S. (2008). Adsorption mechanisms of organic chemicals on carbon nanotubes. Environmental Science and Technology, 42(24), 9005 9013. https://doi.org/10.1021/es801777n

Pandey, L.K., \& Bergey, E.A. (2016). Exploring the status of motility, lipid bodies, deformities and size reduction in periphytic diatom community from chronically metal $(\mathrm{Cu}, \mathrm{Zn})$ polluted waterbodies as a biomonitoring tool. Science of the Total Environment, 550, 372-381. https://doi.org/10.1016/j.scitotenv.2015.11.151

Pandey, L.K., Han, T.,\& Gaur, J.P. (2015). Response of a phytoplanktonic assemblage to copper and zinc enrichment in microcosm. Ecotoxicology, 24(3), 573-582. https://doi.org/10.1007/s10646-014-1405-5

Parial, D., Patra, H. K., Dasgupta, A. K. R.,\& Pal, R. (2012). Screening of different algae for green synthesis of gold nanoparticles. European Journal of Phycology, 47(1), 22-29. https://doi.org/10.1080/09670262.2011.653406

Pate, R.C. (2013). Resource requirements for the large-scale production of alga biofuels. Biofuels, 4(4), 409-435. https://doi.org/10.4155/bfs.13.28

Peña Castro, J. M., Martínez-Jerónimo, F., Esparza-García, F., \& Cañizares Villanueva, R. O.(2004). Heavy metals removal by the microalga Scenedesmus incrassatulus in continuous cultures. Bioresource Technology, 94(2), 219-222. https://doi.org/10.1016/j.biortech.2003.12.005

Pinto, T., Gouveia, L., Ortigueira, J., Saratale, G.D.,\& Moura, P.(2018) Enhancement of fermentative hydrogen production from Spirogyra sp. by increased carbohydrate accumulation and selection of the biomass pretreatment under a biorefinery model. Journal of Bioscience and Bioengineering, 126(2), 226-234. https://doi.org/10.1016/j.jbiosc.2018.02.017

Pohl, P., Kohlhase, M., \& Martin, M.,(1988). Photobioreactors for the axenic mass cultivation of microalgae. In Stadler T, Morillon J, Verdus MC, Karamanos W, Morvan H, Christaen D (eds). Algol Biotechnology. Elsevier Applied Science, London, 209-217.

Rajeshkumar, S., Malarkodi, C., Vanaja, M., Gnanajobitha, G., Paulkumar, K., Kannan, C., \& Annadurai, G. (2013). Antibacterial activity of algae mediated synthesis of gold nanoparticles from Turbinaria conoides. Der PharmaChemica, 5(2), 224-229.

Rajvaiday, N., \&Markendey, K. D.(1998). Treatment of textile industrial effluent. Advances in Environmental science and technology.8, A. P. H Publishing Corporation, New Delhi 6, 51-68 \& 163-172.

Rao, M. D., \&Gautam, P.(2016). Synthesis and characterization of ZnOnanoflowers using Chlamydomonasreinhardtii: a green approach Environmental Progress and Sustainable Energy, 1-7. https://doi.org/10.1002/ep.12315

Rao, P. M., Kumar, R. R., Raghavan, B. G., Subramanian, V.V., \& Sivasubramanian, V.(2011). Application of phycoremediation technology in the treatment of wastewater from a leather-processing chemical manufacturing facility. Water SA, 37, 7-14. https://doi.org/10.4314/wsa.v37i1

Liu, R.L., Gao, X.Y., An, L., Ma, J., Zhang, J.F., \& Zhang, Z.Q. (2015). Fabrication of magnetic carbonaceous solid acids from banana peel for the esterification of oleic acid. Royal Society of Chemistry Advances, 5 (114), 93858-93866. https://doi.org/10.1039/C5RA15767F

Ruiz-Martinez, A., Martin-Garcia N., Romero I., Seco, A.,\& Ferrer, J. (2012). Microalgae cultivation in wastewater: Nutrient removal from anaerobic membrane bioreactor effluent. Bioresource Technology, 126, 247-253. https://doi.org/10.1016/j.biortech.2012.09.022

Salari, Z., Danafar, F., Dabaghi, S., \& Ataei, S. A. (2016). Sustainable synthesis of silver nanoparticles using macroalgaeSpyrogyraVarians and analysis of their 
antibacterial activity. Journal of Saudi Chemical Society, 20(4), 459-464 https://doi.org/10.1016/j.jscs.2014.10.004

Saravanan, R., Mansoob Khan, M., Gupta, V. K., Mosquera, E., Gracia, F., Narayanan, V., \& Stephen, A. (2015). $\mathrm{ZnO} / \mathrm{Ag} / \mathrm{Mn}_{2} \mathrm{O}_{3}$ nanocomposite for visible light induced industrial textile effluent degradation, uric acid and ascorbic acid sensing and antimicrobial activity. Royal Society of Chemistry Advance, 5(44), 34645-34651. https://doi.org/10.1039/C5RA02557E

Schulze, P.S.C., Carvalho, C.F.M., Pereira, H., Varela, J.C.S., \& Barreira, L. (2017). Urban wastewater treatment by Tetraselmis sp. CTP4 (Chlorophyta). Bioresource Technology, 223, 175-183. https://doi.org/10.1016/j.biortech.2016.10.027

Sengar, R. M. S., Singh, \& K. K., Singh.(2011). Application of phycoremediation technology in the treatment of sewage water to reduce pollution load. Indian Journal of Scientific Research, 2(4), 33-39.

Shamsuzzaman, A., Mashrai, H., Khanam, R. N., \& Aljawfi, R. N. (2017) Biological synthesis of $\mathrm{ZnO}$ nanoparticles using $C$. albicans and studying their catalytic performance in the synthesis of steroidal pyrazolines. Arabic Journal of Chemistry, 10(2), 1530-1536.https://doi.org/10.1016/j.arabjc.2013.05.004

Shanmugapriya, R., \& Ramanathan, T. (2011). Screening for antimicrobial activity of crude extracts of Skeletonemacostatum. Journal of Applied Pharmaceutical Science. 1(7), 154-157. ISSN: 2231-3354.

Shiny, P. J., Mukherjee, A., \& Chandrasekaran, N. (2013). Marine algae mediated synthesis of the silver nanoparticles and its antibacterial efficiency. International Journal of Pharmacy and Pharmaceutical Sciences, 5(2), 239-241.

Streets, S.S., Henderson, S.A., Stoner, A.D., Carlson, D.L., Simcik, M.F., \& Swackhamer, D.L. (2006). Partitioning and Bioaccumulation of PBDEs and PCBs in Lake Michigan. Environmental Science and Technology, 40(23), 7263 7269. https://doi.org/10.1021/es061337p

Ahmad, T., \& Danish, M., (2018). Prospects of banana waste utilization in wastewater treatment: A review. Journal of Environmental Management, 205, 330-348. https://doi.org/10.1016/j.jenvman.2017.10.061

Tilak, A.S., Wani, S.P., Datta, A., Patil, M.D., Kaushal, M., \& Reddy, K.R (2017). Evaluation of Ageratum conyzoides in field scale constructed wetlands (CWs) for domestic wastewater treatment. Water Science and Technology, 75(10), 2268-2280. https://doi.org/10.2166/wst.2017.119

Úbeda, B., Gálvez, J.Á., Michel, M., \& Bartual, A.(2017). Microalgae cultivation in urban wastewater: Coelastrum cf. pseudomicroporum as a novel carotenoid source and a potential microalgae harvesting tool. Bioresource Technology, 228, 210-217. https://doi.org/10.1016/j.biortech.2016.12.095

Validi, M. (2001). Bioremediation- An Overview. Pure Applied Chemistry, 73(7), $1163-1172$.

Munagapati, V.S., Yarramuthi, V., Kim, Y., Lee, K.M., \& Kim, D.S. (2018) Removal of anionic dyes (Reactive Black 5 and Congo Red) from aqueous solutions using Banana Peel Powder as an adsorbent. Ecotoxicology and Environmental Safety, 148, 601-607. https://doi.org/10.1016/j.ecoenv.2017.10.075

Venkatesan, R., Karthikayen, R., Periyanayagi, R., Sasikala, V., \& Balasubramanian, V. (2007). Antibacterial Activity of the Marine Diatom, Rhizosoleniaalata (Brightwell,1858) Against Human Pathogens. Research Journal of Microbiology, 2(1), 98-100. ISSN:1816-4935

Vijayakumar, S., \& Manoharan, C. (2012). Studies on cyanobacterial population in industrial effluents. Journal of Algal Biomass Utilization, 3, 39-45.

Walter Mulbry., Shannon Kondrad., \& Jeffrey Buyer. (2008). Treatment of dairy and swine manure effluents using freshwater algae: fatty acid content and composition of algal biomass at different manure loading rates. Journal of Applied Phycology, 20, 1079-1085.https://doi.org/10.1007/s10811-008-9314-8 Williams, M., Kookana, R.S., Mehta, A., Yadav, S.K., Tailor, B.L., \& Maheshwari, B. (2019). Emerging contaminants in a river receiving untreated wastewater from an Indian urban centre. Science of the Total Environment, 647, 1256-1265. 10.1016/j.scitotenv.2018.08.084

Witters, N., Mendelsohn, R. O., Van-Slycken, S., Weyens, N., Schreurs, E., Meers, F., Carleer, R., \& Vangronsveld, J. (2012). Phycoremediatoion a sustainable remediation technology? Conclusion from a case study. I: Energy production and carbon dioxide abatement. Biomass and Bioenergy, 39, 454-469. https://doi.org/10.1016/j.biombioe.2011.08.016

Xie, X., Gao, H., Luo, X., Su, T., Zhang, Y., \& Qin, Z. (2019). Polyethyleneimine Modified Activated Carbon for Adsorption of Cd(II) in Aqueous Solution. Journal of Environmental Chemical Engineering, 7(3),103-183. https://doi.org/10.1016/j.jece.2019.103183

Zahariev, I., Piskin, M., Karaduman, E., Ivanova, D., Markova, I., \& Fachikov, L. (2017). FTIR spectroscopy method for investigation of Co-Ni nanoparticle nanosurface phenomena. Journal of Chemical Technology Metallurgy, 52(5), 916-928. 